\title{
Supply chain alignment as process: Contracting, learning and pay-for-performance
}

\author{
Kostas Selviaridis ${ }^{1}$ \\ Department of Management Science \\ Lancaster University Management School \\ LA1 4YX, Lancaster, United Kingdom \\ Tel: +44(0)1524594602 \\ Email: k.selviaridis@ lancaster.ac.uk \\ Martin Spring \\ Department of Management Science \\ Lancaster University Management School \\ LA1 4YX, Lancaster, United Kingdom \\ Tel.: +44(0)1524592739 \\ Email: $\underline{\text { m.spring@ @lancaster.ac.uk }}$
}

To appear in the International Journal of Operations \& Production Management Accepted: 6 October 2017

\footnotetext{
${ }^{1}$ Corresponding author: Department of Management Science, Lancaster University Management School, Lancaster, LA1 4YX. Tel.:+44(0)1524594602. Email: k.selviaridis@lancaster.ac.uk
} 


\title{
Supply chain alignment as process: Contracting, learning and pay-for-performance
}

\begin{abstract}
Purpose: This paper seeks to understand how buyers and suppliers in supply chains learn to align their performance objectives and incentives through contracting.

Design/methodology/approach: Two longitudinal case studies of the process of supply chain alignment were conducted based on 26 semi-structured interviews and 25 key documents including drafts of contracts and service level agreements.

Findings: The dynamic interplay of contracting and learning contributes to supply chain alignment. Exchange-, partner- and contract framing-specific learning that accumulates during the contracting process is used to (re)design pay-for-performance provisions. Such learning also results in improved relationships that enable alignment, complementing the effect of contractual incentives.
\end{abstract}

Research limitations/implications: The study demonstrates that the interplay of contracting and learning is an important means of achieving supply chain alignment. Supply chain alignment is seen as a process, rather than as a state. Supply chain alignment does not happen automatically or instantaneously, nor is it unidirectional. Rather, it is a discontinuous process triggered by episodic events that requires interactive work and learning.

Practical implications: Development of performance contracting capabilities entails learning how to refine performance incentives and their framing to trigger positive responses from supply chain counterparts.

Originality/value: The paper addresses supply chain alignment as a process. Accordingly, the paper unearths some important features of supply chain alignment.

Keywords: supply chain alignment; inter-organisational relationships; contracting; learning; pay-for-performance. 


\section{Introduction}

An effective supply chain strategy aligns a firm's performance priorities and objectives, and those of its suppliers, with the requirements of customers (van der Vaart and van Donk, 2006; Vachon et al., 2009). This view of alignment is arguably the defining concept of supply chain management: if firms in a supply chain are aligned in achieving the end customer's requirements, then this benefits the supply chain as a whole, as it can improve performance and increase its collective share of the end-customer's business (Christopher and Towill, 2002). Alignment is achieved through inter-organisational relationships, which are governed by a combination of formal contracts and relational norms (e.g. trust) (Cao and Lumineau, 2015; Wacker et al., 2016). These underpin more specific alignment practices, including information sharing, increasing levels of integration and collaboration, and the design of compatible performance measures (Frohlich and Westbrook, 2001; Simatupang and Sridharan, 2002).

To achieve the latter, firms must define and jointly prioritise objectives to reflect supply chain performance requirements (Gunasekaran et al., 2001). They must also align their own incentive systems with these objectives (Lee, 2004), by designing payment mechanisms for their suppliers that reward success and /or penalise failure (i.e., pay-for-performance), and enable sharing of related gains and risks (Hypko et al., 2010). Such mechanisms are embodied in contracts, which have typically been seen as safeguarding tools that protect against opportunism; increasingly, however, contracts are also seen as enablers of inter-firm coordination and alignment (Schepker et al., 2014). Pay-for-performance contracts, in particular, emphasise incentive alignment (Kim et al., 2007; Datta and Roy, 2011), motivating suppliers to achieve the buyer's objectives e.g. cost reduction or innovation (Sumo et al., 2016).

The literature on pay-for-performance contracting is mainly underpinned by agency theory (Eisenhardt, 1989) and transaction cost economics (TCE) (Williamson, 1979) and adopts a contingency view, arguing that contract design depends on the characteristics of buyer 
and supplier and the exchange attributes ( $\mathrm{Zu}$ and Kaynak, 2012; Selviaridis and Wynstra, 2015). For example, pay-for-performance provisions are suitable for incentive alignment in cases of conflicting objectives and information asymmetry (Simatupang and Sridharan, 2002). This focus on supply chain contingencies and their impact on the content of contracts, however, underplays the process by which supply chain counterparts align their objectives and incentives. Alignment through contracts takes place over often extended periods, through relationships characterised by shifting patterns of power and trust, and by processes of learning. And yet, despite the centrality of bounded rationality in their analysis, both TCE- and agencytheory-informed studies treat learning as a trivial matter, dismissing it as something that happens almost instantaneously and thoroughly (Mayer and Argyres, 2004).

We problematise this assumption (Alvesson and Sandberg, 2011), and suggest instead that learning in general, and in contracting specifically, tends to be gradual, through reflection on prior experiences and evolving interactions (Lumineau et al., 2011). Learning entails elaborate group interactions within and between firms to articulate and codify implicit knowledge (Nonaka and Takeuchi, 1995) e.g. about the exchange relationship. Learning enables firms in supply chains to align with their changing environments and market requirements and to improve performance (Matthews et al., 2017).

In this paper, we propose that supply chain alignment is a process partly underpinned by the dynamic interplay of contracting and learning. A process perspective is important also because performance objectives and incentives often must be re-aligned, even long after a contract is agreed (Lee, 2004). Accordingly, the study poses the following research question (RQ): How do buyers and suppliers in supply chains learn to align their objectives and incentives through contracting? 
This RQ is pursued through two in-depth, longitudinal case studies of the process of supply chain alignment. The analysis focuses on the key role of learning in the (re)design of pay-for-performance provisions and the management of inter-firm relationships.

The study contributes to contracting literature by demonstrating that the interplay of contracting and learning is an important means of achieving supply chain alignment. Such alignment, as an outcome of contracting, has not been much in focus by scholars stressing a learning perspective on contracting. The paper also contributes to research on pay-forperformance contracting by demonstrating the learning process by which supply chain counterparts align their objectives and incentives. It also directs attention to the development of performance contracting capabilities, and unpacks the objects of learning that the development of such capabilities entails. In addition, the study contributes to supply chain alignment literature by treating alignment as a process, rather than as a state. It demonstrates that supply chain alignment does not happen automatically or instantaneously, and that it is not unidirectional. Rather, it is a discontinuous process triggered by episodic events (e.g. contract renegotiation) and it entails interactive work and learning. The findings present implications for managers seeking to achieve supply chain alignment.

The next section presents the conceptual background, followed by a discussion of methodology. Subsequently, the two longitudinal case studies are presented and analysed. The last two sections discuss the cross-case findings and draw out research and managerial implications and avenues for further research.

\section{Conceptual background}

Supply chain alignment: possible theoretical perspectives

Alignment is a central concept in both operations strategy and supply chain strategy (van der Vaart and van Donk, 2006). Operations strategy scholars have long argued that a firm's 
resources and capabilities should be aligned with market requirements, through the prioritisation of operations performance objectives e.g. cost or flexibility (Slack and Lewis, 2002). Supply chain strategy extends this logic upstream, arguing that a firm should align its performance priorities with the priorities of its suppliers, which should also be in line with the requirements of the focal firm's customers (Vachon et al., 2009; Gobbi and Hsuan, 2015). Supply chain alignment towards a specific performance objective is contingent and contextdependent: whether firms in a supply chain jointly focus on efficiency (cost) or responsiveness (e.g. flexibility) is determined by the type of product, and demand and supply characteristics (Fisher, 1997; Lee, 2002).

However, although it is useful in some ways to treat them as unified entities, supply chains in fact comprise firms with separate, and more or less diverging, strategic priorities. As such, we need to examine more critically, relationship by relationship, why, how and to what extent alignment actually takes place. Here, we outline various theoretical perspectives that might be adopted to understand this issue.

Agency theory (Eisenhardt 1989) specifically focusses on how the incentives - and hence, it is assumed, actions - of actors with diverging priorities can be aligned. It is directly applicable to supply chain alignment, because it addresses the very question of how performance priorities can be made consistent between principals and agents $\mathrm{Zu}$ and Kaynak, 2012). Indeed, agency theory has been particularly important in the literature on pay-forperformance contracts, as discussed further below. But the broader assumption here is that actors need to be given explicit financial incentives to align their actions with those of supply chain counterparts. This implies that appeals to the general principle of the whole supply chain 'delivering superior customer value' (Christopher, 2005:3) are not enough: further mechanisms such as contracts and related financial incentives are needed to translate potential, longer-term, collective benefits into real, shorter-term individual rewards (e.g. Kim et al., 2007). 
Trust is often considered as an alternative to formal governance mechanisms ${ }^{2}$ based on contracts, as understood in agency theory and TCE. Trust is "a belief or expectation that the vulnerability resulting from the acceptance of risk will not be taken advantage of by the other party" (Lane, 1998:3) in a relationship between interdependent actors. On this view then, supply chain alignment would be achieved not because of explicit incentives but, for example, by counterparts making relationship-specific investments in the expectation of improving overall supply chain performance, even in the absence of formal agreements on, e.g., sharing increased costs and risks.

There is considerable debate about the relationship between contractual governance and trust. They can be seen as substitutes (Cao and Lumineau, 2015): broadly, parties who trust one another have less need for formal governance in the form of extensive contracts. Puranam and Vanneste (2009) frame the problem as a decision about the choice of [formal] governance structure, given certain degrees of pre-existing trust between two firms. They argue that unduly complex governance (extensive contracts) can 'crowd out' trust, undermining the effect of preexisting trust in the success of a relationship. Other accounts suggest that trust and contractual governance act as complements (Poppo and Zenger, 2002). The process of developing and implementing a contract requires parties to interact to explore and define processes for dealing with unexpected circumstances, which arise from the inevitably incomplete nature of contracts and the inability to foresee all eventualities (Roehrich and Lewis, 2014). In this sense, the development of trust aids the development of contractual governance, and vice versa (Cao and Lumineau, 2015). As with TCE more generally, such analyses typically only capture a one-off 'choice' of governance structure: they do not, for example, seek to understand how a given

\footnotetext{
${ }^{2}$ Williamson (1979) uses the term 'governance structure' to refer to "the institutional framework within which the integrity of a transaction is decided. Markets and hierarchies are two of the main alternatives" (Williamson 1979: 235). Also included are hybrids - strategic alliances and other forms that combine elements of the market mechanism of specification and price, and of the hierarchical mechanism, such as monitoring and rules.
} 
level of pre-existing trust has come about, nor how the exchange performance may affect future levels of trust (cf. Puranam and Vanneste, 2009). This points to the value of a processual perspective, which we examine further in this study.

As indicated, much of the debate in the inter-organisational relationships literature contrasts trust with the 'relentless application of calculative economic reasoning' (Williamson 1993:453) as exemplified by TCE. However, trust has also been critically examined in the literature on power (Clegg, 1989), rooted in sociology. Taking a power perspective, alignment can come about without detailed contracts not because of an expectation that the other party will forego taking advantage of a counterpart's vulnerability arising from risky investments and actions, but because other structural factors reduce the choices available. Simple treatments of power in buyer-supply relations (Ramsay 1994) have drawn equivalences between power and dependence: one firm 'has power' over another to the extent that the other firm depends on it for its input supplies/sales. A more sophisticated view (see Clegg et al. 2006), however, would see power as a process, and incorporate the subtler ways in which one actor can shape the 'rules of the game' in a relationship, and mobilise new technologies and methods to change the prevailing institutional logics by which a counterpart evaluates what is in its interest, and what it should do. Power in this sense is something that organisations do, rather than something they have: in a supply chain alignment context, the way power plays out is through the normalisation of practices such as supplier auditing, open-book accounting, or the imposition of standardised logistics processes.

These practices might be seen as evidence of a 'trust-based' supply relationship, and contrasted with contractually-governed, 'adversarial' relationships (e.g. Lamming, 1996). They could also, however, be understood as power masquerading as trust (Hardy et al., 1998). Norms and expectations are typically seen as an aspect of non-contractual governance consistent with trust-based relationships; but shaping what the norms and expectations are is 
an effective and enduring instantiation of power. In this sense, the practices of alignment can also be seen as the practices of power. It should be noted here that power is treated neutrally: power is not necessarily bad, but simply one way to get things done (Hardy and Clegg, 1999).

Our critique of the static, 'one-shot' nature of much TCE and agency-theoretic analysis, combined with the more sophisticated understanding of power - which also moves away from one-off static analysis, albeit of a different kind - suggests the need for a more processual view. The Industrial Marketing and Purchasing (IMP) literature offers some useful insights here. Early IMP research (Håkansson, 1982) drew explicitly on Williamson but presented a longterm developmental perspective on inter-organisational relationships, rather than treating relational contracting as simply an intermediate choice of governance structure. In the original IMP interaction model (Håkansson, 1982), relationships were seen as a sequence of interaction 'episodes' - exchanges of products/services, information, money, or social exchanges - with past episodes influencing present ones, and present episodes being shaped by expectations about future ones. The interaction model also stressed adaptation: firms in a relationship may, deliberately or in a more emergent manner, change aspects of their products/services or pricing so as to adapt to their counterpart. They may deliberately resist adaptation (e.g. refuse to deliver customised services) to retain economies of scale or avoid over-dependence. Alignment in supply chain terms can be seen as a more specific case of the adaptation process.

In summary, the above theoretical perspectives come from very different starting points and focus on different aspects of inter-organisational relationships, but serve to sensitize us to alternative issues in supply chain alignment. They also point, in various ways, to the value of processual rather than static approaches, relevant here because the existing supply chain alignment literature tends to underplay the process of alignment as a result of changing contingencies e.g. performance priorities (Lee, 2004). 


\section{Supply chain alignment, contracting and learning}

The operations and supply chain literature argues that alignment can be achieved by various means, such as integrating processes across firm boundaries (Frohlich and Westbrook, 2001), collaborating and sharing information, and making performance priorities consistent (Simatupang and Sridharan, 2002) by translating them into specific objectives and measures (Gunasekaran et al., 2001). Achieving these performance objectives requires the alignment of supply chain counterparts' incentives (e.g. Narayanan and Raman, 2004), and contracting plays an important part in this (Kim et al., 2007). In particular, buyers use pay-for-performance contracts to tie supplier compensation to the required performance outcomes, thus creating incentives for suppliers to expend effort in the achievement of these outcomes (Datta and Roy, 2011). These incentives can take various forms e.g. a bonus /malus or a gain- /pain-share mechanism (Caldwell and Howard, 2014).

As we have seen, alignment could be understood from a variety of theoretical perspectives. The literature on pay-for-performance contracts draws largely on agency theory and TCE (Selviaridis and Wynstra, 2015), according to which, contract design choices depend on factors pertaining to the contracting parties and the exchange attributes. Agency theory suggests that information asymmetry, objective conflict, outcome uncertainty, outcome measurability, risk aversion of the buyer and supplier, and task programmability determine the choice between a contract that emphasises monitoring of supplier behaviour (behaviour-based), and one that incentivises supplier performance (outcome-based) (Eisenhardt, 1989; Zu and Kaynak, 2012). Pay-for-performance incentives are suitable in cases of conflicting objectives, low outcome uncertainty, high outcome measurability, and low service provider risk aversion (Kim et al., 2007). TCE-informed analysis stresses mainly the role of asset specificity (Williamson, 1979). The level of asset-specific investments influences contract design, since 
suppliers may require duration-related safeguards or incentives (long-term contracts) to prevent buyer opportunism and ensure return on their investments (Selviaridis and Wynstra, 2015).

Although most of the contracting literature focusses on the state of alignment based on a match between contract design and exchange characteristics, some authors have taken a more processual perspective, stressing the role of learning in contract design and the development of contracting capabilities (e.g. Mayer and Argyres, 2004; Ryall and Sampson, 2009; Hartmann et al., 2014). Contracting capabilities entail learning about what provisions and safeguards to include in a contract, when (i.e., under which exchange conditions), and to what level of detail (Mayer and Solomon, 2006; Vanneste and Puranam 2010).

The process of drafting or re-writing contracts fosters learning - about each other's needs, intentions, and expectations, and about the exchange itself e.g. in terms of objectives and tasks (Lumineau et al., 2011). This can feed into subsequent contractual negotiations (Mayer and Argyres, 2004). During contract execution, new information is generated that further enables parties to learn how more effectively to (re)design contracts by adjusting the level of contractual detail (e.g. to clarify responsibilities or plan for contingencies), and to collaborate (Mayer and Argyres, 2004). Such learning tends to be incremental, and experiential rather than vicarious (Argyres et al., 2007). Learning to contract and the development of contracting capabilities are empirically manifested by the level of extensiveness of contracts (e.g. number and detail level of contract provisions, or number of pages) and the reduction in negotiation time required to agree provisions (Ryall and Samspon, 2009; Arino et al., 2014). As successive agreements (or drafts of a contract in-the-making) codify exchange- and partner-specific learning, contracts include more extensive provisions and safeguards and serve as repositories of knowledge (Mayer and Argyres, 2004).

More recent literature suggests another object of learning. During the contracting process, counterparts learn about each other's exchange perceptions and behavioural responses 
to the framing of contractual provisions (Weber et al., 2011). Different ways of framing a contractual provision, which otherwise have identical consequences, may elicit different behavioural responses and views of the buyer-supplier relationship (Cao and Lumineau, 2015). A contractual provision (e.g. pay-for-performance) can be framed as a gain (bonus payment) which is likely to promote creativity, flexibility and a collaborative relationship. Alternatively, it can be framed as a loss (financial penalty) which can induce a vigilant behaviour, close monitoring and an arm's-length relationship (Weber and Mayer, 2011). Learning about the counterpart's perceptions and responses that specific contract frames produce is important as it can trigger the re-framing of provisions to stimulate positive responses and foster collaboration (Cao and Lumineau, 2015).

Learning to contract entails the development of organisational capabilities and is, in that sense, consistent with more general notions of organisational learning. Learning matters, as it enables firms to align with their changing environments and customer requirements (Matthews et al., 2017). According to Nonaka and Takeuchi (1995), learning occurs through group-level interactions within and between organisations, as implicit knowledge held by individuals is articulated and codified as explicit knowledge, through e.g. written plans and instructions. This explicit knowledge can then be shared within and between organisations and later internalised by individuals as it is put into use (Nonaka and Takeuchi, 1995). This knowledge-creation process is relevant to contracting, as groups of individuals involved in contractual negotiations articulate, codify (in contractual documents) and later internalise knowledge regarding the exchange and the buyer-supplier relationship (Lumineau et al., 2011).

In sum, the learning perspective on contracting is consistent with a processual view of supply chain alignment. It helps to examine how buyers and suppliers, through the contracting process, learn about the exchange and each other's needs, perceptions and responses to the framing of contractual provisions. Such learning can inform the (re)design of pay-for- 
performance provisions to achieve supply chain alignment. A notion of learning that focusses on the codification of knowledge is empirically accessible through the analysis of contract documentation (e.g. Mayer and Argyres, 2004). However, we are aware that the relationships in which alignment, learning and contracting take place are infused with processes of power and trust, which are less readily available to us through documentation analysis. This informs our method, discussed in the next section, in that we triangulate documentary evidence with in-depth interviews of managers playing a key role during the contracting process; it also makes it theoretically desirable to keep power and trust perspectives in mind as we analyse our cases of the process of supply chain alignment through contracting.

\section{Research methodology and design}

Given our focus on the process of supply chain alignment, a case study design was adopted to analyse in-depth the specific context and help build theory (Ketokivi and Choi, 2014). Casebased research is suitable for longitudinal, process-oriented investigations (Voss et al., 2002) that aim to make sense of a sequence of events over time, and in context (Pettigrew, 1990). Longitudinal cases are particularly useful for studying the interplay of contacting and learning and evolution in contracts (Mayer and Argyres, 2004). Unlike surveys, case studies facilitate the collection and analysis of contractual documents (Lumineau et al., 2011). In this study, drafts of service level agreements (SLAs) and payment provisions proved instrumental in capturing how supply chain counterparts learn to align their objectives and incentives.

We selected two cases, whereby supply chain counterparts had initiated contractual negotiations to align their objectives and incentives, to track the alignment process longitudinally. Table 1 provides background information about the buying and suppling firms in the two cases. Longitudinal cases present challenges regarding access to data and effort intensity (Voss et al., 2002) and because of that, our sample was limited to two cases. 
[Insert Table 1]

The case selection strategy followed a theoretical sampling approach (Pagell and Wu, 2009; Barratt et al., 2011). Supply chain alignment is influenced by multiple contingencies, many of which are industry-specific (e.g. demand characteristics), and hence we limited our case sampling to a single industry to control for cross-industry differences (Pagell and Wu, 2009). We focused on the logistics industry because, although buyers and logistics service providers (LSPs) have adopted pay-for-performance contracts to achieve alignment (Langley and Capgemini, 2016), they face challenges in designing effective contractual incentives and must climb a steep learning curve in this regard. The process of alignment was therefore relevant in this context.

Our sampling was theoretically motivated also because we selected cases that differed in terms of the counterparts' experience in pay-for-performance, which can influence the process and objects of learning: while in the first case pay-for-performance provisions were introduced for the first time, in the second case pre-existing pay-for-performance provisions were revisited to improve alignment. Case selection also considers the relative size of buyer and supplier firms and the potential role of power-dependence relations in contractual negotiations. Our case sampling reflected such differences in terms of firm size balance between buyers and suppliers (cf. Pagell and Wu, 2009).

Data were collected between November 2011 and June 2014 and involved 26 semistructured interviews with managers, and analysis of 25 key documents. The managers spanned multiple functions including Operations, Business Development (BD), Key Account Management (KAM) from the LSP side, and Logistics and Supply from the buyer side (Table 2). Specific managers playing key roles in the contractual negotiations were interviewed 
multiple times to track the changes in the drafted contracts, and why these were introduced. We interviewed key respondents at regular intervals. However, these intervals were not fixed; additional interviews were being conducted to understand the rationale for contractual changes, as and when these occurred.

[Insert Table 2]

The interview guide included 'open-ended' questions (Miles and Huberman, 1994) and the interviewees were asked to provide a chronology and details of key events that led to contractual changes. Interview themes included the rationale for introducing or revising payfor-performance provisions, contract design challenges, the effects of incentives, and perceptions of other aspects of the relationship such as power, trust, and collaboration.

The process of alignment was reconstructed as a sequence of time- and context-bound events by using a combination of retrospective and real-time data from interviews and documents (Pettigrew, 1990). Retrospective interviewee accounts of early phases of the contracting process were complemented by a high volume of contemporaneous data as the process of negotiating pay-for-performance provisions was tracked in real time (in Case A for a period of 32 months, while in Case B for ten months).

Access was granted to key documents, notably successive versions of SLAs and contract payment and incentive mechanisms, presentation files used during contractual re-negotiations, and performance evaluation records. Document analyses helped reconstruct key contracting events and triangulate interviewee accounts. These documents also proved instrumental in Case A, where access was not granted to managers of the buyer. Access to the successive versions of the payment scheme, which were produced by the buyer jointly with the LSP, contributed 
significantly towards triangulating LSP managers' accounts and ensuring data accuracy and validity (Voss et al., 2002).

Data analysis and coding were performed in line with recommendations by Miles and Huberman (1994). All data were considered to produce rich narratives and within-case analyses. The data were represented visually using figures and tables (see the next two sections) to arrange key events of the contracting process in a chronological order (Yin, 2003). Crosscase analysis was performed to discern patterns (Miles and Huberman, 1994) regarding the alignment process and the interplay of learning and contracting underpinning such alignment.

Data coding was informed by the conceptual background (e.g. the learning perspective and power and trust aspects), but additional codes emerged during the analysis. Open codes (e.g. 'exchange-specific learning', 'partner-specific learning') were initially assigned to interview transcripts and documents, and these were later grouped into higher categories (e.g. 'objects of learning') using axial coding (Voss et al., 2002). Overall, these codes were refined by iterating between data and the literature, as additional data were being collected (Barratt $e t$ al. 2011).

\section{Analysis of the cases}

This section presents the within-case analyses of how buyers and LSPs learn to align their objectives and incentives through contracting, and the dynamics of the alignment process.

\section{Case A}

This case concerns a contractual relationship between a fourth-party logistics provider (hereafter LSPA) and an international food retailer. LSPA began supplying services to the buyer in 1997, supporting the company in the rapid international expansion of its store network. The buyer then changed its emphasis towards supply chain cost efficiency in response to 
slowing growth and customer pressure to reduce food prices. Consequently, the parties jointly decided to revisit the existing cost-plus contract (first version in Table 3) and introduce payfor-performance provisions to re-align their incentives towards cost reduction. Figure 1 summarises the multi-year process of negotiating and drafting the pay-for-performance provisions. Table 3 shows how these provisions evolved in four successive drafts of the contract.

\section{[Insert Figure 1]}

[Insert Table 3]

LSPA managers became aware early on in the process that the buyer intended to stress efficiency targets, because prior performance reviews had indicated that growth in established markets was slowing down. As a result, LSPA's perception of the framing of the original contract payment scheme changed. LSPA managers initially saw the cost-plus management fee provision in a positive light, since it mitigated their financial risk and allowed for flexibility. However, given the changing situation, they came to see it as a dis-incentive for cost reduction. As the LSPA Operations Director explained the transition from the first to the second contract version: "The customer's focus on supply chain cost reduction meant that we would be losing money under a cost-plus contract since our management fee depends on service costs ... we need to renegotiate to align our incentives".

A long process of drafting the details of a 'fixed-price-plus-incentive-fee' principle was initiated. This was facilitated by the absence of a formal re-tendering point in the 12-month rolling contract, and had been foreseen in the first contract version (payment clause): "The Parties agree to continue their discussions regarding a gain-sharing model as a means to incentivise actions for cost reduction by the sharing of achieved savings over an agreed period 
of time with the objective to introduce a new model during 2012”. Prior exchange experiences of the buyer and LSPA informed the drafting process, and so did the accumulating knowledge of each other's needs, objectives, and operating mentalities, and of service operations (see Figure 1).

It was important to determine how the incentive fee would be linked to performance, and how performance would be operationalised and measured. LSPA initially proposed that the incentive fee be tied to product volume increase outcomes and, hence, only indirectly to cost savings. This reasoning was based on accumulated knowledge of the buyer firm's business and the assumption that supply chain cost reduction would help reduce food prices at stores, and hence increase sales and volume throughput. As the LSPA Managing Director commented on the second contract version (Table 3): "We have suggested that we want a model based on volume, but without being given the benefits for things that could be done without our support. Because volumes can go up with building new stores, which has nothing to do with our cost efficiency performance". LSPA was initially reluctant to link the incentive fee directly to cost savings, because it knew that cost reduction outcomes were influenced by several factors (e.g. buyer actions) and thus not easily attributable to LSPA effort. The LSPA BD Manager explained regarding the negotiations of the second contract version: "there is a lot of noise when you are trying to measure cost improvements [...] we won't be able to measure the improvements as clearly as we would like to connect them to our revenue".

LSPA's proposal to link payment to volume outcomes was, however, rejected due to the buyer's understanding that sales and product volume growth were partly independent of LSPA's supply chain planning effort. Instead, the buyer insisted that the incentive fee be linked directly to cost savings. This was reflected in the third version of the contract, which also specified the product availability KPI as a 'qualifier' for triggering incentive payments. At that point (Event 4) the buyer essentially exerted its bargaining power to impose its requirement on 
LSPA to link the incentive fee to cost savings targets. Given the fact that this specific customer account formed a large part of the provider's total revenue, LSPA eventually acceded to the buyer's request. As the LSPA Operations Director admitted: “[...] we are quite dependent on this client, I mean it's a big part of our business".

Through the contracting process, LSPA managers became conscious of the complex interrelations between cost reduction, volumes and service levels and their implications for the design of performance incentives. Specifically, cost efficiency initiatives could negatively influence store service levels and volume throughput in the LSPA network, thus reducing LSPA-driven efficiencies. The LSPA BD Manager explained the challenges related to negotiating the third contract version: "when we reduced the service to cut costs, they actually took out volume which means less economies of scale, increasing cost for the volumes that are left".

Learning about the counterparts' responses to incentive framing was also important. Initially the buyer proposed that the cost reduction incentive include both a bonus and penalty fee, which was rejected by LSPA, given the cost savings attribution challenges and the supply chain complexity and dynamism. A penalty fee (see second contract version) was perceived as too risky: "From our point of view penalties are excluded [...] we hope that we got them [buyer] to a state where the base is very low margin and then the bonus is on top of that as a kick-back” (LSPA, BD Manager). Consequently, the parties re-drafted the incentives and, according to a presentation file used during negotiations (May 2013), the buyer agreed to a "bonus system in relation to operational performance and cost". The third version (Table 3) stipulated that the bonus size would be determined based on amount of cost savings generated and product availability against the $93 \%$ target. This provision was refined in the fourth version to specify that no bonus would be paid if product availability were to drop below $83 \%$. 
While designing the gain-share mechanism, LSPA managers worried that they were unlikely to receive a salient bonus because of the high annual cost savings targets. During negotiating the third and fourth contract versions, LSPA managers became familiar with the buyer's attitude to pay-for-performance: "They have the mentality that we need to reach almost $100 \%$ to get a bonus...if [targets] are not achievable, then the bonus will be something that we won't budget for" (LSPA, Business Developer). Because of this attitude, LSPA instead emphasised securing an appropriate fixed price. LSPA managers initially proposed to link the fixed price element to an index reflecting varying service complexity levels arising from changes in the buyer's supply chain. This approach, with additional allowances reflecting buyer growth and any extra services, was subsequently adopted (see fourth version). In this way, LSPA mitigated its financial exposure.

Overall, Table 3 suggests that pay-for-performance provisions were being re-drafted as parties were growing aware of service delivery intricacies and each other's needs and responses to the proposed frames of performance incentives. This process also instigated learning about the respective LSPA and buyer responsibilities and actions that would promote collaboration to achieve the cost reduction objective. This joint learning helped to reinforce trust between the counterparts, but at the same time the pre-existing trust built based on past relationship successes influenced the contracting process. The pay-for-performance provisions contributed to aligning the objectives and incentives of the buyer and LSPA, but there was a common understanding that the new contractual provisions would be subject to adjustments to further improve such alignment (see Event 7). LSPA interviewees referred to the importance of maintaining the trustful relationship and stressed the need to remain flexible to revisit the contract in case it failed to achieve incentive alignment. To this end, the parties also deliberately designed a pay-for-performance mechanism that did not require complicated performance 
monitoring systems which would potentially create a "finger-pointing", arm's length atmosphere in the relationship and erode trust.

\section{Case B}

This case concerns a contract for transport management services between a manufacturer of packaging production machines and a global LSP (henceforth LSPB). The exchange relationship was established in 2003, but pay-for-performance provisions were first introduced in the contract only in 2012 to instigate LSPB continuous performance improvement and innovation. The process of buyer and LSPB alignment and the related events are summarised in Figure 1. Table 4 shows how key pay-for-performance provisions were revisited and refined in three successive versions of the SLA.

[Insert Table 4]

In 2012 a bonus/ malus clause and a mechanism to share cost savings resulting from LSPB innovation were included in the contract (first version in Table 4). This reflected the strategic priorities of the buyer in relation to sustainability performance (more specifically carbon emissions reduction across the supply chain) and innovation-driven cost reduction. The buyer established and implemented related performance measurement and auditing practices in all its supplier relations. Consequently, LSPB was also made to accept measuring and reporting carbon emissions and service innovation-driven savings against annual targets.

The LSPB interviewees initially perceived the specific framing of these provisions positively, because of the gain-share principle and the higher weighting assigned to bonus for performance achievement as compared to penalties for performance shortcomings. This positive view was reflected, for instance, by the LSPB Global KAM referring to the first 
contract version: "[The buyer] needed us to support them to achieve cost efficiency [...] so that was the SLA with the penalty and bonus scheme and we would have something to gain as well".

The provisions were first implemented in 2013 and, soon after, it became evident that they did not trigger LSPB performance improvements as effectively as had been envisaged. The incentives as designed at that stage tied LSPB payment to the buyer's strategic supply chain goals, namely innovation, cost reduction (while maintaining end customer service levels), and environmental supply chain performance. In principle, this would align the incentives of the buyer and LSPB. In practice, however, the parties faced challenges with respect to: (a) definition of innovation performance and related cost reductions, and (b) attribution of performance in terms of emissions reduction and on-time deliveries to end customers. These difficulties instigated revisions and refinements to the pay-for-performance provisions.

The buyer found LSPB insufficiently proactive in performance improvement and innovation, while LSPB interviewees reported that the buyer would not agree that certain innovative ideas were developed and owned by LSPB, and that it would claim ownership of the supplier's innovative ideas during performance review meetings. At the end of 2013 an annual performance evaluation was conducted and the LSPB was asked to pay a financial penalty based on its under-performance on four KPIs and an overall performance score below 3.0 (Table 4). This event and the related contractual deficiencies triggering episodes of opportunism eroded trust and caused temporary strain in the relationship, as LSPB perceived the imposed penalty fee as unfair, not least because several performance aspects such as 'carbon emissions' and 'deliveries accuracy' (first contract version) had been influenced by the actions of the buyer and transport sub-contractors. As the LSPB Global KAM exemplified: "The transport accuracy KPI is hard to hit because we are dependent on carriers' performance”. 
Over time, LSPB managers understood better the complexity of the buyer's supply chain and the requirements of the buyer's customers e.g. regarding delivery lead times. The parties also faced difficulties in clearly separating 'logistics cost reduction' from 'freight cost reduction' outcomes as specified in the SLA, and the buyer's role in enabling innovations in service delivery. For example, LSPB suggested that packaging machines be transported on ship-deck, rather than 'under-deck', to save loading /unloading time. However, this innovation entailed changes in the product architecture, and these were resisted by the buyer's production department.

Once the buyer recognised that external factors were affecting outcomes and that the LSPB had made significant freight cost savings, they decided to excuse LSPB from paying the penalty stipulated in the first contract version: "Even though we got the savings we wanted and even higher, the overall score was still below the target. So we didn't want to get the penalty [...]. They didn't do well in terms of emissions reduction, but this was affected by decisions and actions of [our customers] " (Buyer, Outbound Logistics Manager). Negotiations allowed the joint identification of several factors affecting LSPB performance, and the adjustment of pay-for-performance provisions. More specifically, the accumulated service delivery-specific learning allowed refinement of two KPIs: what 'logistics cost reduction' meant, and how the freight cost reduction outcomes should be calculated route by route (second version, Table 4).

The parties subsequently agreed on the need to refine the KPIs and their weighting, and the measurement method for some of them ('carbon emissions' and 'deliveries accuracy'). LSPB requested that all buyer-driven decisions to use airfreight for urgent deliveries should be excluded from the LSPB-inflicted carbon emissions and the incentive fee calculation. There was also agreement on a process for documenting innovative ideas from LSPB that could result in cost savings. The buyer's decision to excuse LSPB from paying the financial penalty and 
the subsequent joint work to refine the pay-for-performance provisions (see Events 5-6) helped to restore trust between the counterparts to a large extent.

However, during this SLA adjustment process, and despite their original positive perception of pay-for-performance provisions, LSPB interviewees expressed concerns about the fairness of the incentives scheme. The LSPB Air and Outsourcing Manager commented during the negotiations of the third contract version: "We need to have clear and fair KPIs in place, which are controllable by us, or we are in agreement that we can handle them. We have tried to change the weighting of the KPIs based on what we can control". These negotiations led to a third version of the SLA which was more elaborate in terms of the KPI matrix and performance incentives (Table 4). The incentive fee was also restricted to LSPB administration work and decoupled from costs outside LSPB's control.

Examination of the successive SLA versions suggests that the parties gradually developed an understanding of the factors influencing performance, and each other's exchange perceptions. Buyer managers also gained an insight into the impact the SLA framing had on LSPB response to risk, and used this to refine relevant provisions in the third contract version: "They [LSPB] were surprised with the level of the penalty that they would have to pay [...]. That was also a reason for changing the basis of the incentive model for this year" (Buyer, Outbound Logistics Manager).

Such learning collectively influenced the adjustment of pay-for-performance provisions to improve incentive alignment. Buyer interviewees argued that the revised contract (second and third versions) contributed to LSPB behaviour change and closer alignment towards the buyer's goals: It [SLA] has been an absolutely positive experience and we got their attention; we are seeing a change in their mind-set and it is quite nice to see that they are focusing on hitting the targets, generating ideas for improvement" (Buyer, Global Supply Manager). This 
was confirmed by LSPB managers: "This [SLA] has helped to change our mentality and to think in terms of performance improvement" (LSPB, Global KAM).

\section{Discussion}

In what follows we revisit the RQ posed in the introduction: How do buyers and suppliers in supply chains learn to align their objectives and incentives through contracting? The findings suggest that the dynamic interplay of contracting and learning contributes to supply chain alignment by affecting both the pay-for-performance contractual provisions and the buyersupplier relationship more broadly. As a result of the contracting process, exchange- and partner-specific learning is accumulated (Lumineau et al., 2011). Such learning concerns the exchange features (e.g. service characteristics and factors influencing performance targets) as well as the counterparts' objectives, needs, actions and operating mentalities. In addition, contracting parties learn about each other's perceptions and responses to the framing of the contract (Weber et al., 2011). This object of learning refers specifically to the counterparts' perceptions of risk and exchange fairness in response to the way pay-for-performance provisions are framed e.g. penalty/ bonus, intensity of performance targets and salience of incentives. Both cases demonstrated that exchange-, partner- and contract framing-specific learning develops gradually as counterparts interact and reflect upon prior exchange experiences (Lumineau et al., 2011).

The above objects of learning are used to revisit pay-for-performance provisions so as to achieve alignment. In other words, learning arising from the contracting process triggers further negotiations and contract re-design (Argyres and Mayer, 2007). Both cases demonstrate how parties gradually learn to contract e.g. by designing more effective performance incentives. However, the exchange-, partner-, and contract framing-specific learning may not be fully captured in revised pay-for-performance provisions (Vanneste and Puranam, 2010), but instead 
result in improved relationships by promoting collaboration and trust (Mayer and Argyres, 2004). Such improved relationships enable the alignment of objectives and incentives between buyers and suppliers (Lee, 2004), complementing the effect of pay-for-performance provisions. Figure 2 depicts this dynamic interplay of learning and contracting, and its effects on pay-forperformance contract design, buyer-supplier relationships and alignment.

[Insert Figure 2]

Comparative analysis of the two cases suggests that the rationale for alignment determines whether the interplay of contracting and learning results in a relative emphasis on the design of contractual provisions or on the (collaborative) relationship. In Case A, the rationale was the changing performance priorities in the supply chain. The case emphasises how parties learn, during contracting-related interactions (Lumineau et al., 2011), to shape a shared definition of these changing performance priorities and operations trade-offs (e.g. volumes, costs and service levels), and to re-align their objectives. In this case, improved buyer-supplier collaboration and trust were instrumental for re-alignment. Such collaborative relationship was manifested through the joint intention to revisit the cost-plus contract to address incentive misalignments, the identification of required buyer and third-party actions contributing to supply chain cost reduction, and the mitigation of performance attribution challenges by explicating external uncontrollable factors influencing supply chain costs.

In contrast, Case B stresses how alignment can be improved by using accumulating knowledge regarding the effects of pay-for-performance contract, and its unintended consequences. The case shows how parties learn to design more effective pay-for-performance contract provisions (Mayer and Argyres, 2004) by using actual data from prior implementation of such provisions to refine KPIs, and elaborate upon the incentive scheme. Examples of 
learning that was used to address existing contractual deficiencies included awareness of the role of the buyer in achieving certain performance targets, the imbalances in KPI weights, and deficiencies in KPI measurement methodologies.

The two cases present differences with respect to the role of power and trust vis-à-vis contracting and the process of supply chain alignment. Regarding power, the cases differ in terms of how power was exerted by the buyer during the contracting process. In Case A, the dependence of the supplier on the buyer (Ramsay, 1994) in terms sales revenue meant that the supplier had to accept the buyer's request to link part of the payment to supply chain cost savings (and not to product volumes) during a specific episode of the contractual negotiations. The supplier's dependence on the buyer was mainly due to firm size imbalance, with the buyer's business forming a very large part of the supplier's total revenues. In contrast, in Case B, where the buyer and supplier were of similar size, power played out in the subtler way suggested by Clegg et al. (2006) in that the buyer socialised the supplier (and all its other suppliers) into accepting performance monitoring and reporting practices related to the buyer's strategic focus on sustainability, innovation and cost. In this sense, the buyer shaped the 'rules of the game' and these were also reflected in the contract through the bonus /malus and the gain share provisions, which were linked to carbon emission reduction and innovation-related cost saving targets.

Trust also played out differently in the two cases in relation to contracting and the process of alignment. In Case A the pre-existing trust (Puranam and Vanneste, 2009) facilitated the process of adjusting the contract payment mechanism to re-align the counterparts' incentives. In this case, trust functioned as a complement to formal /contractual governance (Roehrich and Lewis, 2014) in that both parties were not relying only on the contract and accepted that payfor-performance provisions may need to be revisited in case they failed to contribute to alignment. In Case B, on the other hand, trust and contract functioned mainly as substitutes 
(Cao and Lumineau, 2015): deficiencies in the design of pay-for-performance contract provisions and related disputes eroded pre-existing trust, albeit only temporarily. The learning that occurred during the process of contractual renegotiation (e.g. that the supplier was hardly responsible for failures to reduce carbon emissions) and the buyer's decision to excuse the supplier from paying the penalty that the contract stipulated helped to restore trust and facilitate alignment later in the process. In that specific episode, then, the formal contract was ignored in the interest of restoring trust and fairness in the relationship (Cao and Lumineau, 2015).

The findings can offer broader insights regarding the role of contracting in achieving supply chain alignment. The notion of the perfectly aligned supply chain delivering superior value to end-customers with minimum cost and shared benefits to chain members (Christopher, $2005)$ is challenging to translate into the actual practice at each relationship. Firms in the supply chain may simply not know how to achieve the ideal outcomes of the perfectly aligned supply chain, or they may not want to because of their diverging priorities and interests (Lee, 2004). Contracting and contracts have a role here - contracts provide information by explicating and specifying performance objectives (of immediate customers) conducive to the ideal outcomes of the aligned supply chain. In addition, contracts help translating these ideal outcomes into more concrete incentives that potentially contribute to alignment (cf. Kim et al., 2007).

However, contracting is part of the solution and its interaction with other elements such as trust and power in achieving alignment should be considered. On a more speculative level, contracts with less detailed specifications allowing flexibility may be considered as manifestation of trust and complement relational governance (Vanneste and Puranam, 2010), but they may also reflect a power relationship in that open-ended contractual specifications result from the powerful party's expectation that it can request from its counterpart to adapt to changing requirements at short notice. In this sense, alignment could be achieved through exerting power with the open-ended contract facilitating this process. 


\section{Conclusions}

This section concludes by discussing research and managerial implications as well as future research opportunities.

\section{Research implications}

The paper contributes to two research areas: (a) contracting and, more specifically, pay-forperformance contracting, and (b) supply chain alignment. These contributions are discussed in turn below.

This study demonstrates that the interplay of contracting and learning is an important means of achieving supply chain alignment, by allowing supply chain counterparts to align their performance goals and incentives. Such alignment, as an outcome of contracting, has not been much in focus by scholars stressing a learning perspective on contracting (e.g. Lumineau et al., 2011). Our study also offers some initial insights regarding the interaction of contracting and power relations during the process of alignment. Although the contracting literature has examined the complex interactions between contracting, trust and learning (e.g. see Mayer and Argyres, 2004; Vanneste and Puranam, 2010), it has yet to consider the role of power.

In relation to pay-for-performance contracting research, more specifically, this study shows that learning is important in the process of alignment in that buyers and suppliers learn to design more effective pay-for-performance contracts e.g. designing effective incentive systems (Caldwell and Howard, 2014). Compared to research using agency theory and TCE, which adopts a static view of contract design and alignment (e.g. Hypko et al., 2010; Zu and Kaynak, 2012), our study captures the learning process by which supply chain counterparts align their objectives and incentives, and it directs attention to the development of performance contracting capabilities. Specifically, the study unpacks the objects of learning that the development of performance contracting capabilities entails; amongst other things, learning 
about the counterparts' perceptions and responses to contract frames, and learning to re-frame contracts accordingly, is an important aspect. In this sense, this paper builds upon recent research on performance contracting capabilities (e.g. Hartmann et al., 2014; Spring and Araujo, 2014). In our study, these capabilities are manifested via the gradual elaboration of pay-for-performance provisions as counterparts learn to gauge KPIs, and refine performance incentives and their framing.

The second area to which our paper contributes is the supply chain alignment literature. Our study shows that contracting is as a central mechanism for supply chain alignment, although it has been underplayed in the operations and supply chain literature (e.g. Frohlich and Westbrook, 2001; Vachon et al., 2009). Focussing on pay-for-performance contracting, our study has demonstrated just one important way in which supply chain alignment can be seen a process, rather than a state. Our work builds on existing research on supply chain alignment (e.g. Lee, 2004) by identifying the processes by which contractual performance objectives and incentives of buyers and suppliers are used to align and re-align supply chains in response to changing performance priorities or other contingencies, and the types of learning that this entails. This contrasts with previous studies taking a contingency view of alignment (e.g. Narayanan and Raman, 2004; Kim et al., 2007) and underplaying the role of learning.

More generally, through contracting or indeed any other mechanism, we show that supply chain alignment does not happen automatically. Firms and managers have choices about which, if any, of their customers' requirements to translate into requirements upon their own suppliers (Easton and Araujo, 1997). Neither does alignment happen instantaneously. It entails effort and takes time, to interpret and understand customers' requirements, and then to work out how to achieve the required alignment with suppliers, through adjustments to contracts or through other mechanisms. In this sense, there is not a unidirectional transmission of objectives, incentives and performance, but an interactive process of learning and re-learning between 
buyers and suppliers. It also seems likely that alignment is never perfect (see also Lee, 2004): certainly, there is a good deal of trial and error and unintended consequences; some of the effectiveness of the customer's incentives is likely to be lost or distorted in transmission; and alignment is always a work-in-progress. Finally, and as a consequence of the realities of cognition and the processes of contracting and interaction between supply chain counterparts, alignment is to a greater or lesser extent discontinuous, being brought about in part by episodic events (Håkansson, 1982) such as contract renewals and periodic performance reviews.

\section{Managerial implications}

The findings present implications for managers seeking to achieve alignment with their supply chain counterparts through contracting. The development of performance contracting capabilities entails learning about how to gauge the framing of pay-for-performance provisions to elicit positive reactions from counterparts. Managers should set performance targets at appropriate levels of intensity and should also consider the marginal benefits and costs of bonus payments to complement and reinforce any initial positive perceptions of bonus-related provisions. The design and framing of pay-for-performance provisions should be evaluated in the context of specific exchange goals as the same provision (e.g. payment mechanism) can stimulate different reactions at different points in time, given changing performance objectives in the supply chain.

Different objects of learning may need stressing by managers, depending on the rationale for supply chain alignment. Exchange- and partner-specific learning is more important when drafting pay-for-performance provisions for the first time to address changing performance priorities and objectives, and potential future misalignments. In such cases the counterparts' reactions to frames of provisions are based on assumptions and projections of the future, rather than on actual data and feedback from prior implementation experiences. Learning about 
exchange characteristics and each other's aims and intentions results in improved ability to collaborate to achieve the re-set objectives. On the other hand, learning regarding existing contractual deficiencies and perceptions and responses to the way provisions are framed may be more important when refining existing pay-for-performance provisions to improve alignment. Learning to re-frame provisions to elicit positive behaviours from counterparts is a key contracting capability in such instances.

\section{Limitations and future research}

We have studied the process of supply chain alignment in relation to contracting. A more holistic treatment of alignment requires a processual understanding of other important mechanisms, such as information sharing among supply chain counterparts. Although our study offers some initial insights into the interaction of power and contracting in the process of alignment, further research is needed to develop a better understanding of this interaction and its effects. In addition, the paper has not examined the effects of learning on firm and supply chain performance. Future research should address this aspect in line with a broader interest in the impact of formal contracts on performance (Cao and Lumineau, 2015). The lack of access to the buying firm in Case A potentially limits our findings, although the analysis of documents produced by the buyer to complement missing data and triangulate supplier interviewees' accounts largely ensured validity. The findings' generalisability is restricted by the case-based design, though the longitudinal cases offer rich insights into the process of supply chain alignment. Survey research across industries and legal-institutional contexts could help refine our theoretical understanding of supply chain alignment as process. 


\section{References}

Alvesson, M. and Sandberg, J. (2011), "Generating research questions through problematization, Academy of Management Review, Vol. 36 No. 2, pp. 247-271.

Arino, A. Reuer, J. Mayer, K. and Jane, J. (2014), "Contracts, negotiation, and learning: An examination of termination provisions, Journal of Management Studies, Vol. 51 No. 3, pp. $379-405$.

Argyres, N. Bercovitz, J. and Mayer, K. (2007), "Complementarity and evolution of contractual provisions: An empirical study of IT services contracts." Organization Science, Vol. 18 No, 1, pp. 3-19.

Argyres, N. and Mayer, K. (2007), "Contract design as a firm capability: An integration of learning and transaction cost perspectives", Academy of Management Review, Vol. 32 No. 4, pp. 1060-1077.

Barratt, M. Choi, T. and Li, M. (2011), "Qualitative case studies in operations management: Trends, research outcomes and future research implications", Journal of Operations Management, Vol. 29, pp. 329-342.

Caldwell, N. and Howard, M. (2014), "Contracting for complex performance in markets of few buyers and sellers: The case of military procurement", International Journal of Operations \& Production Management, Vol. 34 No. 2, pp. 270-294.

Cao, Z. and Lumineau, F. (2015), "Revisiting the interplay between contractual and relational governance: A qualitative and meta-analytic investigation", Journal of Operations Management Vol. 33-34, pp. 15-42.

Christopher, M. (2005), Logistics and Supply Chain Management: Creating Value-adding Networks ( $3^{\text {rd }}$ Edition), Pearson Education, Harlow.

Christopher, M. and Towill, D. (2002), "Developing market specific supply chain strategies", International Journal of Logistics Management, Vol. 13, No. 1, pp. 1-14.

Clegg, S. (1989), Frameworks of Power, Sage, London.

Clegg, S., Courpasson, D. and Phillips, N. (2006), Power and organizations, Sage, London.

Datta, P. and Roy, R. (2011), "Operations strategy for the effective delivery of integrated industrial product-service offerings: Two exploratory defense industry case studies", International Journal of Operations \& Production Management, Vol. 31 No. 5, pp. 579-603.

Easton, G. and Araujo, L. (1997), "Interfirm responses to heterogeneity of demand over time" in Ebers, M. (Ed.) The Formation of Interorganisational Networks, Oxford University Press, Oxford, pp. 66-94.

Eisenhardt, K. (1989), “Agency theory: An assessment and review”, Academy of Management Review, Vol. 14 No. 1, pp. 57-74. 
Fisher, M. (1997), "What is the right supply chain for your product?", Harvard Business Review, Vol. 75 No. 2, pp. 105-16.

Frohlich, M. and Westbrook, R. (2001), "Arcs of integration: an international study of supply chain strategies", Journal of Operations Management, Vol. 19 No. 2, pp. 185-200.

Gobbi, C. and Hsuan, J. (2015), "Collaborative purchasing of complex technologies in healthcare", International Journal of Operations \& Production Management, Vol. 35 No. 3 pp. 430-455.

Gunasekaran, A. Patel, C. and Tirtiroglu, E. (2001), "Performance measures and metrics in a supply chain environment", International Journal of Operations \& Production Management, Vol. 21 No.1/2, pp. 71-87.

Hardy, C., Phillips, N. and Lawrence, T. (1998), "Distinguishing trust and power in interorganizational relationships: forms and facades of trust", In Lane, C. and Bachmann, R. (Eds.) Trust Within and Between Organisations: Conceptual Issues and Empirical Applications, Oxford University Press, Oxford, pp. 64-87.

Hardy, C. and Clegg, S.R. (1999), "Some dare call it power", In Clegg, S. R. and Hardy, C. (Eds.) Studying Organization: Theory and Method, Sage, London, pp. 368-387.

Hartmann, A. Roehrich, J. Fredriksen, L. and Davies, A. (2014). "Procuring complex performance: The transition process in public infrastructure", International Journal of Operations \& Production Management, Vol. 34 No. 2, pp. 174-194.

Håkansson, H. (1982), International Marketing and Purchasing of Industrial Goods, John Wiley, Chichester.

Hypko, P. Tilebein, M. and Gleich, R. (2010), "Clarifying the concept of performance-based contracting in manufacturing industries: A research synthesis", Journal of Service Management, Vol. 21 No. 5, pp. 625-655.

Ketokivi, M. and Choi, T. (2014), "Renaissance of case research as a scientific method", Journal of Operations Management, Vol. 32, pp. 232-240.

Kim, S. Cohen, M. and Netessine, S. (2007), "Performance contracting in after-sales service supply chains", Management Science, Vol. 53, No. 12, pp. 1843-1858.

Lamming, R. (1993), Beyond Partnership: Strategies for Innovation and Lean Supply, Prentice-Hall, Hemel Hempstead.

Lane, C. (1998), "Introduction: theories and issues in the study of trust", in Lane, C. and Bachmann, R. (Eds.) Trust within and between organisations: conceptual issues and empirical applications, Oxford University Press, Oxford, pp. 1-30.

Langley, J. and Capgemini (2016), 2016 Third-Party Logistics Study: The State of Logistics Outsourcing, Capgemini. 
Lee, H.L. (2004), “The triple-a supply chain”, Harvard Business Review, Vol. 82 No. 10, pp. 102-113.

Lee, H.L. (2002), "Aligning supply chain strategies with product uncertainties", California Management Review, Vol. 44, No. 3, pp. 105-119.

Lumineau, F. Frechet, M. and Puthod, D. (2011), "An organizational learning perspective on the contracting process." Strategic Organization, Vol. 9 No. 1, pp. 8-32.

Matthews, R., MacCarthy, B. and Braziotis, C. (2017), "Organisational learning in SMEs: a process improvement perspective", International Journal of Operations \& Production Management, Vol. 37 No. 7, pp. 970-1006.

Mayer, K. and Argyres. N. (2004), "Learning to contract: Evidence from the personal computer industry”, Organization Science, Vol. 15 No. 4, pp. 394-410.

Mayer, K. and Solomon, R. (2006), "Capabilities, contractual hazards, and governance: Integrating resource-based and transaction cost perspectives, Academy of Management Journal, Vol. 49, No. 5, pp. 942-959.

Miles, M. and Huberman. A (1994). Qualitative Data Analysis: An Expanded Sourcebook, Sage, Newbury Park.

Narayanan, V. and Raman, A. (2004), "Aligning incentives in supply chains", Harvard Business Review, Vol. 82, No. 11, pp. 94-103.

Nonaka, I. and Takeuchi, H. (1995), The Knowledge-Creating Company: How Japanese Companies Create the Dynamics of Innovation, Oxford University Press, New York.

Pagell, M. and Wu, Z. (2009), "Building a more complete theory of sustainable supply chain management using case studies of ten exemplars", Journal of Supply Chain Management Viol. 45 No. 2, pp. 37-56.

Pettigrew, A. (1990), "Longitudinal field research on change: Theory and practice," Organization Science, Vol. 1, pp. 267-292.

Puranam, P. and Vanneste, B. (2009), "Trust and governance: Untangling a tangled web", Academy of Management Review, Vol. 34 No. 1, pp. 11-31.

Ramsay, J. (1994), "Purchasing power", European Journal of Purchasing and Supply Management, Vol. 1 No. 3, pp.125-138.

Roehrich, J. and Lewis, M. (2014), "Procuring complex performance: Implications for exchange governance complexity", International Journal of Operations \& Production Management, Vol. 32 No. 2, pp. 221-241.

Ryall, M. and Sampson, R. (2009), "Formal contracts in the presence of relational enforcement mechanisms: Evidence from technology development projects", Management Science, Vol. 55 No. 6, pp. 906-925. 
Schepker, D., Oh, Y-W. Martynov, A. and Poppo, L. (2014), "The many futures of contracts: Moving beyond structure and safeguarding to coordination and adaptation", Journal of Management, Vol. 40 No. 1, pp. 193-225.

Selviaridis, K. and Wynstra, F. (2015), "Performance-based contracting: a literature review and future research directions", International Journal of Production Research, Vol. 53 No. 12, pp. 3505-3540.

Simatupang, T. and Sridharan, R. (2002), "The collaborative supply chain", International Journal of Logistics Management, Vol. 13 No. 1, pp. 15-30.

Slack, N. and Lewis, M. (2002), Operations Strategy, Prentice-Hall, Harlow.

Spring, M. and Araujo, L. (2014), "Indirect capabilities and complex performance: Implications for procurement and operations strategy", International Journal of Operations \& Production Management, Vol. 34 No. 2, pp. 150-173.

Sumo, R. van der Valk, W. van Weele, A. and Bode, C. (2016), "Fostering incremental and radical innovation through performance-based contracting in buyer-supplier relationships", International Journal of Operations \& Production Management, Vol. 36 No.11, pp. 14821503.

Vachon, S., Halley, A. and Beaulieu, M. (2009), "Aligning competitive priorities in the supply chain: the role of interactions with suppliers", International Journal of Operations \& Production Management, Vol. 29 No. 4, pp. 322-340.

van der Vaart, T. and van Donk, D-K. (2006), "Buyer-focused operations as a supply chain strategy", International Journal of Operations \& Production Management, Vol. 26 No. 1 pp. 8-23.

Vanneste, B. and Puranam, P. (2010), "Repeated interactions and contractual detail: Identifying the learning effect", Organization Science, Vol. 21 No. 1, pp. 186-201.

Voss, C. Tsikriktsis, N. and Frohlich, M. (2002), "Case research in operations management", International Journal of Operations \& Production Management, Vol. 22, No. 2, pp. 195-219.

Wacker, J., Yang, C., and Sheu, C. (2016), “A transaction cost economics model for estimating performance effectiveness of relational and contractual governance", International Journal of Operations \& Production Management, Vol. 36 No. 11, pp. 1551-1575.

Weber, L. and Mayer, K. (2011). Designing effective contracts: Exploring the influence of framing and expectations. Academy of Management Review, Vol. 36, pp. 53-75.

Weber, L. and Mayer, K. and Macher, J. (2011), "An analysis of extendibility and early termination provisions: The importance of framing duration safeguards", Academy of Management Journal, Vol. 54, pp. 182-202.

Williamson, O. E. (1993), "Calculativeness, trust and economic organization”, Journal of Law and Economics, Vol. 36 No.1, pp. 453-486. 
Williamson, O.E. (1979), "Transaction-cost economics: The governance of contractual relations", Journal of Law and Economics, Vol. 22, No. 2, pp. 233-261.

Yin, R. K. (2003), Case Study Research: Design and Methods, Sage, Thousand Oaks.

$\mathrm{Zu}, \mathrm{X}$. and Kanyak, H. (2012), "An agency theory perspective on supply chain quality management”, International Journal of Operations \& Production Management, Vol. 32 No. 4, pp.423-446. 
Table 1. Overview of the cases and the case study companies

\begin{tabular}{ll}
\hline Buyer & Case A \\
\hline $\begin{array}{l}\text { Industry and competitive } \\
\text { environment }\end{array}$ & $\begin{array}{l}\text { Food retail: high level of competition. Focus on } \\
\text { product cost /price and service levels in terms of } \\
\text { product availability at stores. Driving product } \\
\text { volumes and scale economies is crucial for this } \\
\text { market and for the buyer more specifically. }\end{array}$
\end{tabular}

No. of employees

30,000

Turnover

$€ 1,400$ million

LSP (Supplier)

LSPA: Fourth-party logistics provider specialising mainly in food retail sectors. Additional expertise includes pharmaceutical and healthcare logistics.

Industry and competitive environment

No. of employees

Turnover

Services provided to buyer

History and evolution of relationship

\section{Contract term}

Pay-for-performance contract provisions
Contract logistics services: high level of competition in the market. Cost /price the 'order winner', although the ability to respond quickly to customer needs is also a key requirement.

$€ 90$ million

Product supply and demand management, product purchasing, ERP solution, business development and consulting, finance, logistics network management, inventory management.

Since the beginning (1997) of their 19-year relationship and until the late 2000s, the parties grew together as LSPA (sole supplier) was benefiting from the rapid growth of the buyer and its introduction of new stores in existing and new markets. This helped to develop a collaborative relationship and trust based on goodwill but also LSPA competence. Since 2012 the emphasis changed to supply chain cost efficiency in line with increased competition and food price reduction trends. Both parties made relationship specific investements e.g. LSPA established companies in remote markets (e.g. Australia) to be able to own the buyer's products and import /export them. The buyer adjusted its operations and supply functions to the LSPA's distribution network and invested in supply chain improvement projects requested by LSPA.

1-year rolling contract (no need for renewal)

Decision to introduce incentives in the contract was taken in late 2011 to re-align interests towards supply chain cost reduction goal. Long contracting and negotiations process to re-design the payment mechanism and introduce the pay for performance incentives

\section{Case B}

Manufacturer of packaging solutions and industrial packaging production machines

Packaging: competitive market with high growth potential as consumers turn to packaged food. Competitive priorities include cost, product quality and service levels as customer expectations are rising. Reducing carbon footprint across the supply chain an additional strategic priority of the buyer.

$€ 11,075$ million

LSPB: specialising in freight forwarding, and air \& ocean freight transport. Operating globally and in multiple markets, with expertise in FMCG, fashion, industrials and retail.

Contract logistics services: highly competitive market with emphasis on service cost /price and high levels of customer service and responsiveness.

30,000

$€ 6,800$ million

Freight forwarding, shipment booking and coordination, customs clearance, invoice administration and cost control, carrier tendering and performance monitoring.

The parties have been involved in a 13-year relationship. In 2004 the internal shipping department of the buyer was outsourced to LSPB, which operates as a single supplier of transport and logistics services for the delivery of packaging machines to the buyer's customers globally. Despite the good working relationship between the parties and the trust developed based on LSPB competence, the buyer regularly re-tenders for the services to make sure that value for money is maintained. In response to increasing market pressures to reduce cost and carbon footprint, in 2012 the buyer suggested that a bonus /malus mechanism is included in the contractual relationship to increase collaboration and drive LSPB proactive improvement in these areas. LSPB operations and key account managers are colocated in the buyer's headquarters to closely coordinate logistics activities.

\section{2-year contract (renewed at regular intervals)}

Pay-for-performance incentives were firstly introduced in the contract in 2012. They were revisited in 2014 after the first year of their implementation to restore trust and to improve incentive alignment given contractual deficiencies and initial difficulties of triggering appropriate supplier efforts and alignment. 
Table 2. The list of interviewed managers

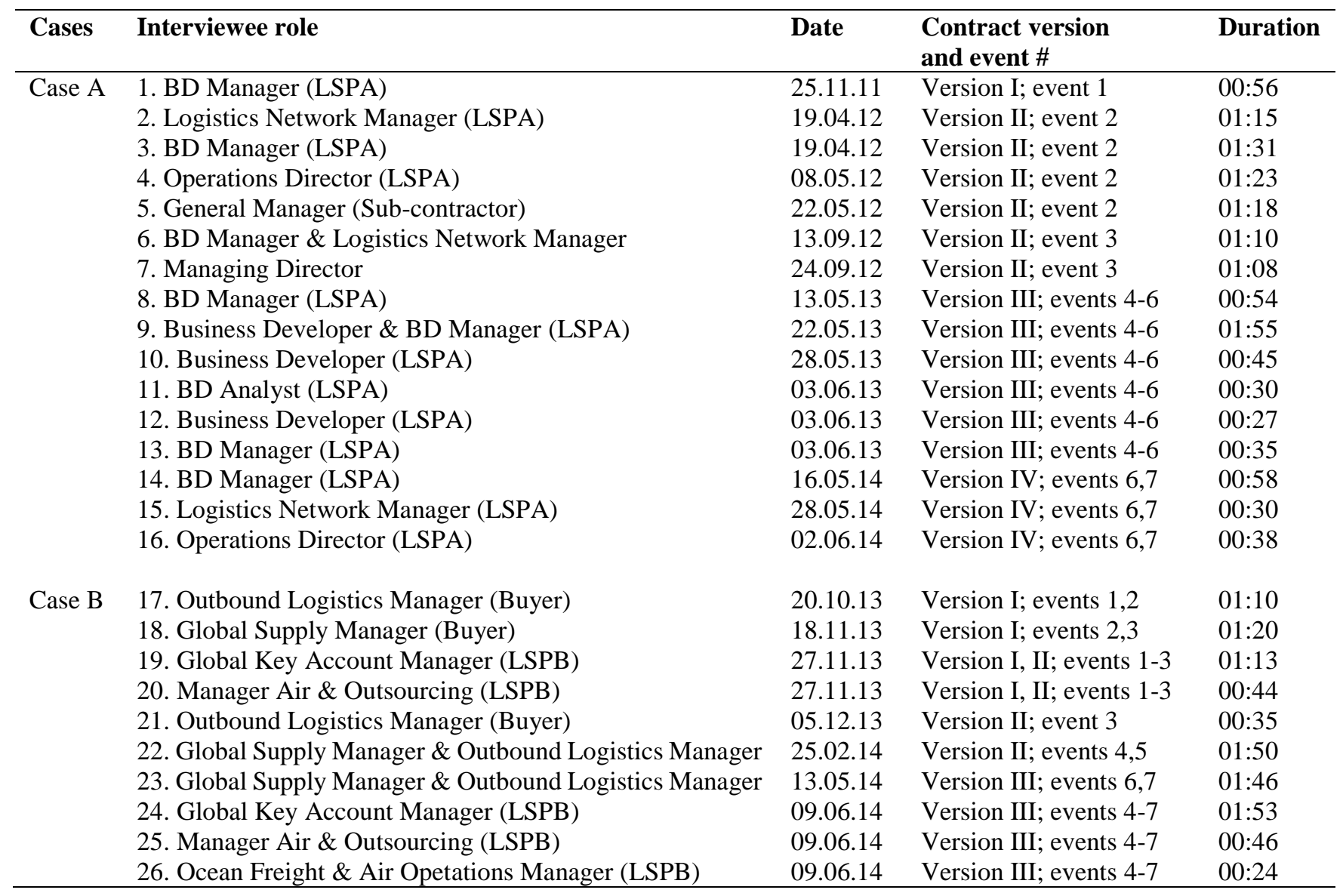


Table 3. Evolution of pay-for-performance contract provisions in Case A (Source: interviews and documents)

\begin{tabular}{|c|c|c|c|c|}
\hline & Version I & Version II & Version III & Version IV \\
\hline $\begin{array}{l}\text { Key } \\
\text { performance } \\
\text { indicators }\end{array}$ & $\begin{array}{l}\text { Transport delivery accuracy } \% \\
\text { Picking accuracy } \% \\
\text { Product damages } \% \\
\text { 'Perfect orders' (OTIF) \% } \\
\text { Product availability \% (at } \\
\text { stores and central warehouse) } \\
\text { Supply chain cost per annum } \\
\text { (including transport, } \\
\text { warehousing, export/import, } \\
\text { customs, duties and product } \\
\text { labelling costs) }\end{array}$ & $\begin{array}{l}\text { Emphasis on } \\
\text { reduction of supply } \\
\text { chain cost (\%) per } \\
\text { annum } \\
\text { Modification of cost } \\
\text { KPI to 'supply chain } \\
\text { cost reduction \%' (as } \\
\text { compared to cost } \\
\text { baseline from } \\
\text { previous year) }\end{array}$ & $\begin{array}{l}\text { Product availability } \% \mathrm{KPI} \text { as } \\
\text { a qualifier for incentive fee } \\
\text { calculation }\end{array}$ & $\begin{array}{l}\text { [No changes from } \\
\text { previous version] }\end{array}$ \\
\hline $\begin{array}{l}\text { Payment } \\
\text { mechanism }\end{array}$ & $\begin{array}{l}\text { Cost-plus-management-fee } \\
\text { Management fee calculated as } \\
\% \text { of actual costs incurred by } \\
\text { LSPA (includes supply chain } \\
\text { costs above plus LSPA admin } \\
\text { costs) }\end{array}$ & $\begin{array}{l}\text { Shift to fixed-price- } \\
\text { incentive-fee } \\
\text { Incentive fee to be } \\
\text { linked to an agreed } \\
\text { metric of } \\
\text { 'performance' }\end{array}$ & $\begin{array}{l}\text { LSPA proposal to link fixed } \\
\text { price element to an index to } \\
\text { account for service } \\
\text { complexity level and changes } \\
\text { in service parameters e.g. } \\
\text { number of markets and } \\
\text { stores, complexity of } \\
\text { markets, food supplier } \\
\text { changes }\end{array}$ & $\begin{array}{l}\text { Agreed to set minimum } \\
\text { fixed price, which is } \\
\text { also adjusted annually } \\
\text { based on buyer's } \\
\text { growth and service } \\
\text { complexity (index } \\
\text { cancelled) } \\
\text { Agreed to cater for extra } \\
\text { fees (on hourly basis) } \\
\text { for out of scope services } \\
\text { performed by LSPA }\end{array}$ \\
\hline $\begin{array}{l}\text { Performance } \\
\text { incentives }\end{array}$ & $\begin{array}{l}\text { None; contract reference to } \\
\text { commitment of both parties to } \\
\text { continue discussions about } \\
\text { introducing a 'gain-share' } \\
\text { mechanism connected to } \\
\text { supply chain cost savings } \\
\text { targets }\end{array}$ & $\begin{array}{l}\text { LSPA proposed link } \\
\text { of incentive fee to } \\
\text { 'product volumes' } \\
\text { outcomes (indirect } \\
\text { link to supply chain } \\
\text { cost reduction) } \\
\text { Buyer proposed } \\
\text { inclusion of both } \\
\text { bonus and penalties }\end{array}$ & $\begin{array}{l}\text { Buyer proposed link of } \\
\text { incentive fee directly to } \\
\text { supply chain cost reduction } \\
\text { and operational performance } \\
\text { targets } \\
\text { Proposed incentive in the } \\
\text { form of 'gain-share' with } \\
\text { bonus only (no penalties). } \\
\text { Savings share to LSPA: } \\
<25 \% \text { saving }=0 \% \\
25-50 \% \text { saving }=30 \% \\
50-75 \% \text { saving }=40 \% \\
75 \%-100 \% \text { saving }=50 \% \\
>100 \% \text { saving }=30 \% \\
\text { Buyer proposal to reduce } \\
\text { bonus if 'product availability' } \\
\text { is lower than } 93 \% \text { target } \\
\text { (even if supply chain cost } \\
\text { savings target is hit). }\end{array}$ & $\begin{array}{l}\text { Moderate bonus agreed. } \\
\text { Bonus payment only if } \\
>90 \% \text { of supply chain } \\
\text { cost saving target } \\
\text { achieved. Bonus } \\
\text { increases substantially } \\
\text { only if LSPA achieves } \\
>99 \% \text { of cost saving } \\
\text { target } \\
\text { No bonus payment for } \\
\text { cost savings if product } \\
\text { availability is below } \\
83 \% \text { threshold }\end{array}$ \\
\hline $\begin{array}{l}\text { Interview } \\
\text { sources } \\
\text { (interview \#) }\end{array}$ & Interview 1 & Interviews 2-7 & Interviews 8-13 & Interviews $14-16$ \\
\hline
\end{tabular}


Table 4. Evolution of pay-for-performance contract provisions in Case B (Source: interviews and documents)

\begin{tabular}{|c|c|c|c|}
\hline & Version I & Version II & Version III \\
\hline $\begin{array}{l}\text { Key } \\
\text { performance } \\
\text { indicators }\end{array}$ & $\begin{array}{l}\text { Total freight cost reduction \% } \\
\text { Ocean freight cost reduction \% } \\
\text { Air freight cost reduction \% } \\
\text { Deliveries Accuracy \% } \\
\text { Accuracy of sailing list when using } \\
\text { multiple carriers \% } \\
\text { Carbon emissions reduction \% } \\
\text { End customer satisfaction survey score } \\
\text { (> specified threshold) } \\
\text { Logistics cost reduction \% (resulting } \\
\text { from supplier innovations) }\end{array}$ & $\begin{array}{l}\text { Clarified definition of } \\
\text { what counts as 'logistics } \\
\text { cost reduction' and } \\
\text { separation from' 'freight } \\
\text { cost reduction' KPIs } \\
\text { Baseline for freight cost } \\
\text { reduction targets } \\
\text { calculated based on } \\
\text { transport route by route } \\
\text { comparison (not } \\
\text { average) }\end{array}$ & $\begin{array}{l}\text { New KPI introduced to capture end } \\
\text { customer claims and complaints for } \\
\text { product damage/ loss } \\
\text { Revised definition of 'deliveries } \\
\text { accuracy' to allow for ocean carriers } \\
\text { 48-hour buffer practice } \\
\text { Changes in measurement method of } \\
\text { carbon emissions to reflect } \\
\text { technological updates; updated } \\
\text { conversion factors used to calculate } \\
\text { grams of carbon emissions per } \\
\text { ton*km }\end{array}$ \\
\hline $\begin{array}{l}\text { Payment } \\
\text { mechanism }\end{array}$ & $\begin{array}{l}\text { Unit-price-plus-incentive-fee } \\
\text { Unit price refers to LSPB shipment } \\
\text { administration (per shipment) } \\
\text { Incentive fee includes LSPB } \\
\text { administration, freight, handling and } \\
\text { forwarding costs }\end{array}$ & $\begin{array}{l}\text { [No changes from } \\
\text { previous version] }\end{array}$ & $\begin{array}{l}\text { Incentive fee excludes freight, } \\
\text { handling and forwarding costs. Focus } \\
\text { on LSPB administration costs for fee } \\
\text { calculation }\end{array}$ \\
\hline $\begin{array}{l}\text { Performance } \\
\text { incentives }\end{array}$ & $\begin{array}{l}\text { Bonus /malus is linked to all KPIs, except } \\
\text { for 'logistics cost reduction \%'. Bonus or } \\
\text { malus is calculated based on overall } \\
\text { performance score (weighted KPIs): } \\
\text { Score 5: }+3 \% \\
\text { Score 4: }+1.5 \% \\
\text { Score 3: } 0.0 \% \text {; } \\
\text { Score 2: }-0.5 \% \text {; } \\
\text { Score 1: }-1.0 \% \\
\text { Gain share model for the KPI 'logistics } \\
\text { cost reduction \%'. Cost savings sharing } \\
\text { mechanism introduced: } \\
<5 \% \text { saving=10\% share for [LSPB] } \\
\text { 5-20\% saving= 25\% share for [LSPB] } \\
>20 \% \text { saving= 50\% share for [LSPB] }\end{array}$ & $\begin{array}{l}\text { [No changes from } \\
\text { previous version] }\end{array}$ & $\begin{array}{l}\text { Incentive fee and gain share } \\
\text { calculations to be adjusted based on } \\
\text { changes in KPI weights (e.g. } \\
\text { increased KPI weights for logistics } \\
\text { cost reduction \% and carbon } \\
\text { emissions reduction \%) } \\
\text { Provision to log and agreed on LSPB- } \\
\text { initiated service innovations resulting } \\
\text { in 'logistics cost reduction' } \\
\text { Specification of buyer actions that } \\
\text { contribute to increase of air freight } \\
\text { shipments (influencing carbon } \\
\text { emissions and air freight cost } \\
\text { reduction targets). Provision to } \\
\text { exclude these from bonus/malus } \\
\text { calculation. }\end{array}$ \\
\hline $\begin{array}{l}\text { Interview } \\
\text { sources } \\
\text { (interview \#) }\end{array}$ & Interviews $17-20$ & Interviews 19-22 & Interviews 23-26 \\
\hline
\end{tabular}


Case A

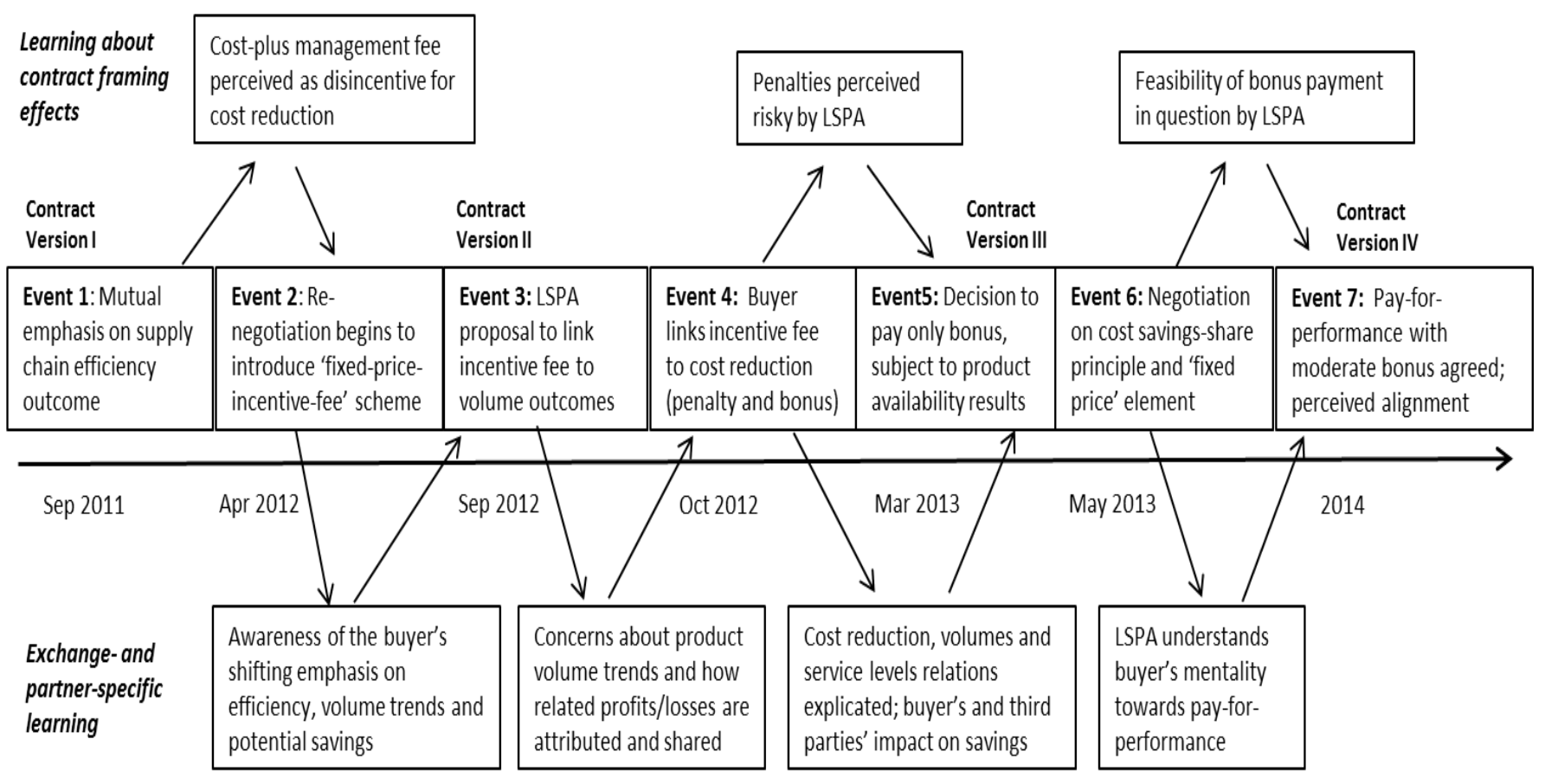

Case B

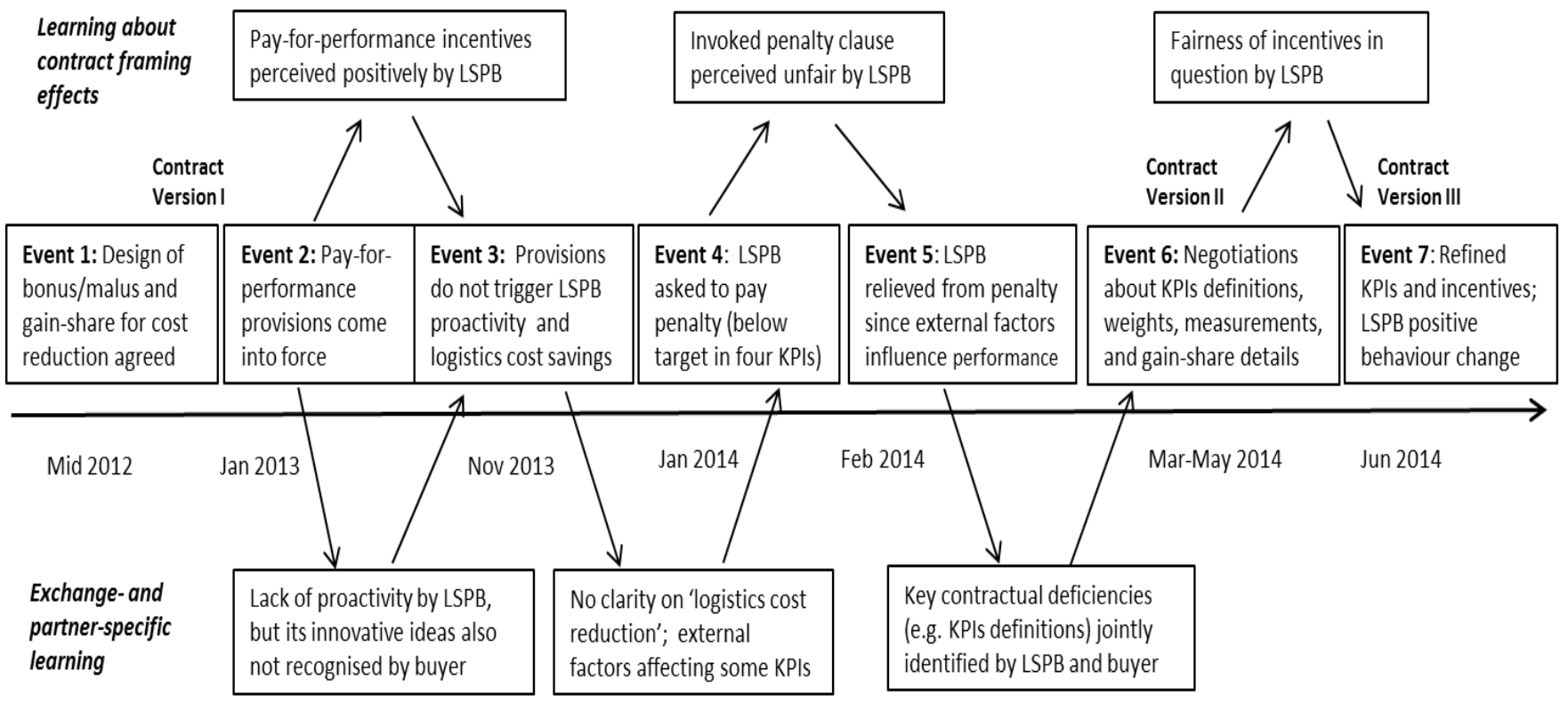

Figure 1. The process of (re)aligning performance objectives and incentives in case A and case B 


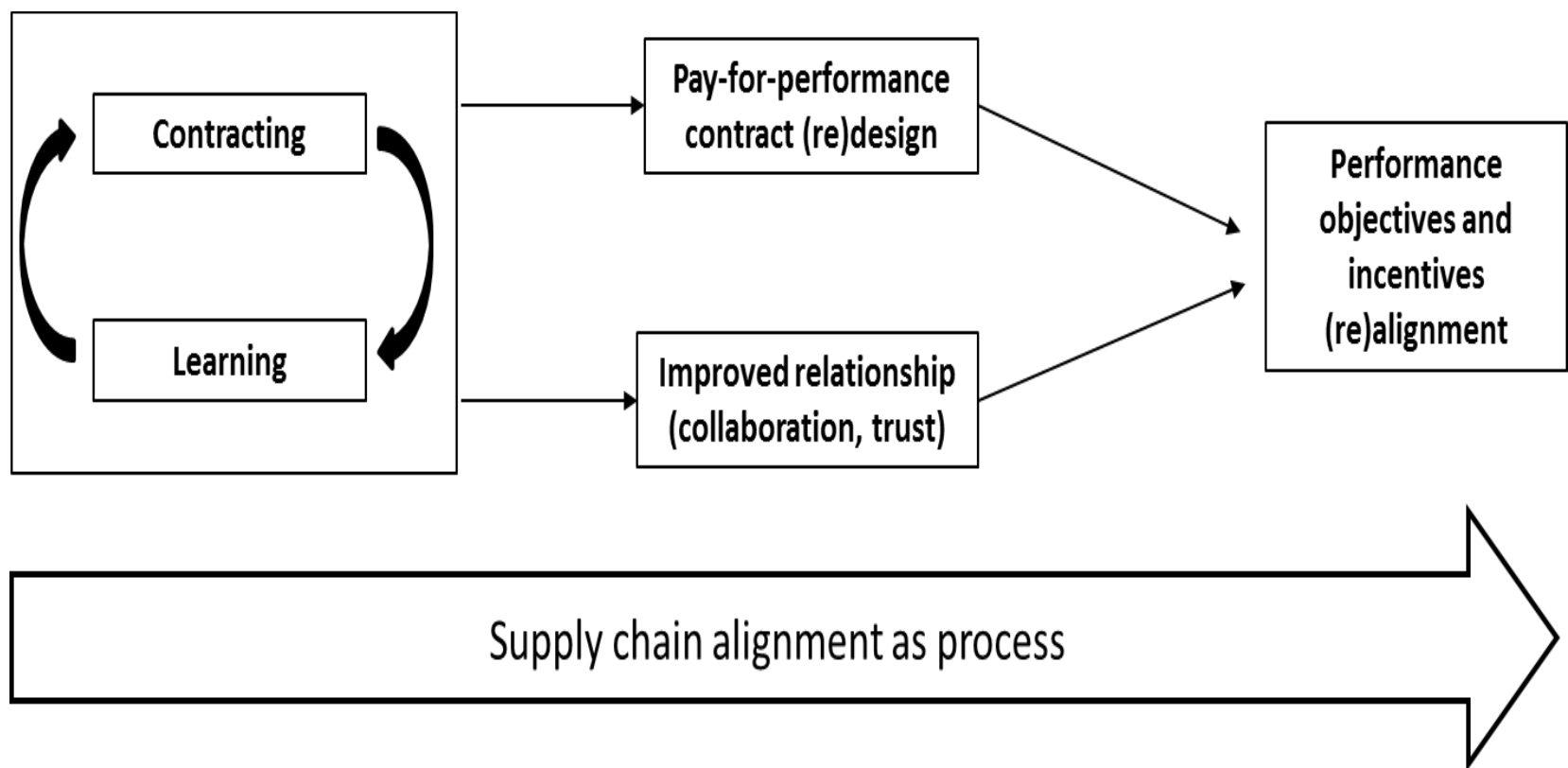

Figure 2. Supply chain alignment as process: The dynamic interplay of contracting and learning and its effects on pay-for-performance contract design, buyer-supplier relationships and alignment. 